\title{
MRI による仙骨春索腫の浸潤様式の検討
}

$\begin{array}{cllllll}\text { 長崎大学整形外科 } & & & & \\ \text { 西 } & \text { 口 } & \text { 雅 } & \text { 彦・平 } & \text { 野 } & & \text { 徹 } \\ \text { 神 } & \text { 代 } & \text { 敏 } & \text { 之. 岩 } & \text { 崎 } & \text { 勝 } & \text { 郎 } \\ \text { 櫛 } & \text { 田 } & \text { 学・山 } & \text { 口 } & \text { 和 } & \text { 博 } \\ \text { 渡 辺 } & \text { 毅 } & & & & \\ \text { 佐世保市立総合病院整形外科 } & & & & \end{array}$

前田公·吉良秀秋

\section{MRI Study of Growth Patterns of Sacral Chordomas}

by

Masahiko Nishiguchi, Toru Hirano, Toshiyuki Kumashiro,

Katsuro Iwasaki, Manabu Kushida, Kazuhiro Yamaguchi and Tsuyoshi Watanabe

Department of Orthopaedic Surgery, Nagasaki University School of Medicine

Hiroshi Maeda and Hideaki Kira

Department of Orthopaedic Surgery, Sasebo Public Hospital

The growth patterns of sacral chordomas were studied in 4 cases by MRI before surgery. The size of the tumor in each patient was $6 \times 6 \times 6 \mathrm{~cm}, 6 \times 9 \times 7 \mathrm{~cm}, 9 \times 7 \times 6 \mathrm{~cm}$ and $11 \times 16 \times 14 \mathrm{~cm}$, respectively. As the tumors increased in size, the structure of the sacrum was destroyed aggressively, and muscles such as gluteus maximus, piriformis and coccygeus were involved irregularly. However, only slight tumor invasion into the sacral spinal canal was seen in all cases. The rectal wall or the sacro-iliac joints were never involved. These results indicated that the growth patterns of sacral chordomas differed dependent upon the specific tissue surrounding the tumors.

Key Words : sacral chordoma (仙骨脊索腫), magnetic resonance imaging (MRI), growth pattern（発育様式）

はじめに

脊索腫は仙椎に好発する原発性悪性骨腫瘍で, 日整 会骨軟部腫瘍登録によると，我国の年間発生数は 10 例以下と非常に稀なものである4).このため脊索腫が どの様に発育・浸潤していくか充分に検討されていな い.この点を明らかにすることは, 腫瘍摘出の際の重 要な情報を提供すると思われる，そこで我々は，大き さの異なる 4 例の仙骨脊索腫の拡がりを MRI で観察 し，その発育・浸潤様式を検討した。

\section{対象および方法}

対象は当教室および関連病院で MRIを行い外科的 に治療した仙骨脊索腫 4 例である. 男性 3 例女性 1 例 で, それらの年齢分布は 57 歳から 75 歳, 平均 68 歳 であった。 それぞれの罹病期間は 3 カ月から 4 年, 平 均 22.5力月で, 神経症状として坐骨神経領域の知覚 障害と膀胱直腸障害が 3 例に認められた（表 1 ).

腫瘍の拡がりを観察するための MRI には GENERAL ELECTORIC 社 1.5Tesla, 東芝社 1.0Tesla を用いた. $\mathrm{T} 1$ 強調・ $\mathrm{T} 2$ 強調画像を撮影し, 腫瘍の大 
表 1 対象症例の臨床所見の詳細

\begin{tabular}{|c|c|c|c|c|}
\hline & 症例 1 & 症例 2 & 症例 3 & 症例 4 \\
\hline 性 別 & 男 & 男 & 女 & 男 \\
\hline 年齢 (歳) & 75 & 57 & 73 & 67 \\
\hline 罹病期間 & 3 力月 & 3 年 & 4 年 & 3 力月 \\
\hline 主 訴 & $\begin{array}{l}\text { 臂 部 痛 } \\
\text { 排尿困難 }\end{array}$ & 左薢部痛 & $\begin{array}{l}\text { 仙骨部痛 } \\
\text { 便 秘 }\end{array}$ & $\begin{array}{l}\text { 擎 部 痛 } \\
\text { 両足底のシビレ }\end{array}$ \\
\hline 知覚障害 & + & - & + & + \\
\hline 膀胱直腸障害 & + & - & + & + \\
\hline
\end{tabular}

表 2 各症例の MRI 所見の詳細

\begin{tabular}{c|c|c|c|c}
\hline \hline & 症例 1 & 症例 2 & 症例 3 & 症例 4 \\
\hline 腫瘍径 $(\mathrm{cm})$ & $6 \times 6 \times 6$ & $6 \times 9 \times 7$ & $9 \times 7 \times 6$ & $11 \times 16 \times 14$ \\
腫瘍高位 & $\mathrm{S} 3$ 椎体 & $\mathrm{S} 3$ 下縁 & $\mathrm{S} 2$ 下縁 & $\mathrm{S} 2$ 下縁 \\
仙骨内浸潤 & 不規則 & 不規則 & 不規則 & 不規則 \\
尾骨の残存 & + & + & + & - \\
筋組織への浸潤 & 軽度 & 中等度 & 中等度 & 高度 \\
直腸壁への浸潤 & なし & なし & なし & なし \\
脊 柱 管 内 浸 潤 & 軽度 & 軽度 & 軽度 & 軽度 \\
仙腸関節への浸潤 & なし & なし & なし & なし \\
\hline
\end{tabular}

きさをMRIにおける最大縦径・横径・前後径で表わ した. 腫瘍の浸潤態度の観察のため, 部位を仙骨, 骨 盤腔内, 脊柱管および周囲筋組織に分けそれぞれにお ける拡がりを検討した. そして腫瘍の大きさと部位別 の浸潤の程度との関係について調べた.

\section{結}

\section{果}

症例 $1 ， 2 ， 3$ および 4 の腫瘍の大きさはそれぞれ $6 \times 6 \times 6 \mathrm{~cm}, 6 \times 9 \times 7 \mathrm{~cm}, 9 \times 7 \times 6 \mathrm{~cm}$ およ び $11 \times 16 \times 14 \mathrm{~cm}$ であった（表 2$)$ ，骨盤腔へはいず れも圧迫性に増殖しており, 直腸壁に浸潤していたも のはなかった．また脊柱管への浸潤も軽度であった。 これに対して仙骨に付着している大殿筋・梨状筋およ び尾骨筋などへは結節性に浸潤しており, 腫湯が大き いものでは広範におよんでいた。仙腸関節へ浸潤して いた症例はなかった。

以下に 4 症例の MRI 所見を供覧する.

症例 1 : T1 で low, T2 で high の大きさ $6 \times 6 \times 6$ cm の腫瘍が sagital では S3 椎体下縁に不規則に浸 潤していた. 脊柱管内の浸潤は軽度で尾骨の下端は残 存していた. axial では骨盤腔内へ圧排性に発育して

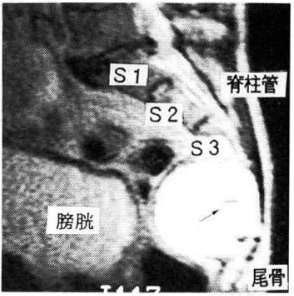

T2 sagital

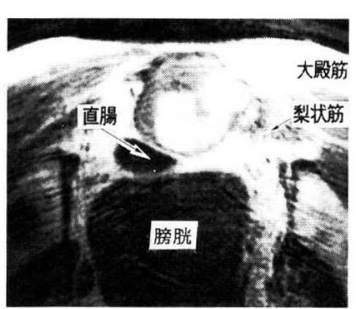

$\mathrm{T} 1$ axial
図 1 症例 1.75 歳, 男性 膀胱や直腸壁と腫塲との境界は明瞭であり, 春 柱管内への浸潤は軽度である. 右図の腫瘍内 $\rightarrow$ 印は, 残存した仙椎椎間板を示す.

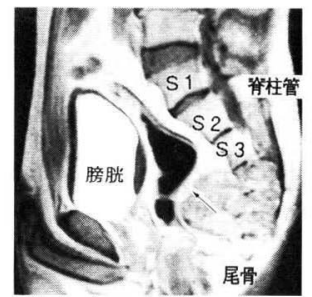

T1 sagital

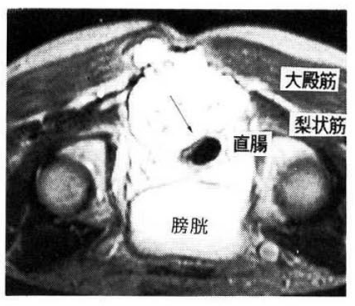

T2 axial
図 2 症例 2.57 歳, 男性 症例 1 と同様 $\rightarrow て ゙$ 示すように腫瘍と直腸壁との 境界は明瞭であったが, 大殿筋, 梨状筋内へは 結節状に浸潤していた.

いるが, 比較的周囲との境界は明瞭で直腸壁への浸潤 はなかった，仙骨に付着部をもつ大殿筋や梨状筋には 結節状に浸潤していた。仙腸関節への浸潤はみられな かった（図 1 ).

症例 2 : 大きさ $6 \times 9 \times 7 \mathrm{~cm}$ の腫瘍が, sagital で はS3 下縁にみられ, 脊柱管内への浸潤は軽度で尾骨 の下端は残存していた. axial では腫瘍は骨盤腔内へ 圧排性に発育していたが, 直腸壁との境界は鮮明であっ た. 周囲大殿筋・梨状筋へは結節状に浸潤していた。 仙腸関節への浸潤はみられなかった（図 2 ).

症例 3 : 大きさ $9 \times 7 \times 6 \mathrm{~cm}$ の腫瘍が sagital で $\mathrm{S} 2$ の下縁にみられたが脊柱管内への浸潤は軽度であった。 尾骨の下端は残存している. axial で骨盤腔内へは圧 排性に発育し, 直腸への浸潤はみられない. 仙骨に付 着する大殿筋や梨状筋には結節状に浸潤していた，仙 腸関節には浸潤はみられなかった（図 3 ).

症例 4 : 大きさ $11 \times 16 \times 14 \mathrm{~cm}$ の巨大な腫瘍で, sagital ではS2 椎体下縁にあり尾骨は破壊されていた。 直腸や脊柱管内への浸潤は見られなかった. axial で は腫瘍内部は多結節性で大殿筋・梨状筋・尾骨筋内人 


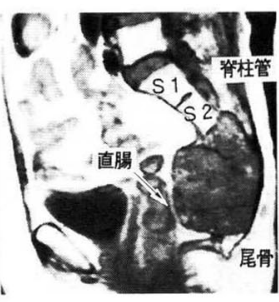

T1 sagital

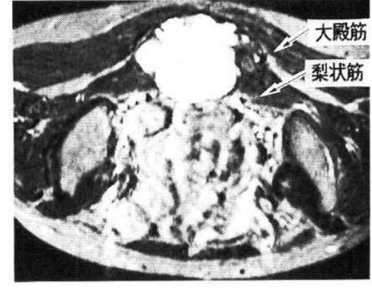

T2 axial
図 3 症例 3.73 歳, 女性 $\mathrm{S} 2 / 3$ 椎間板で腫瘍の第 2 仙椎への浸潤はブロッ クされている.

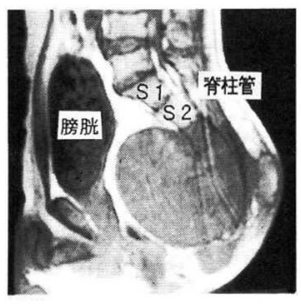

T1 sagital

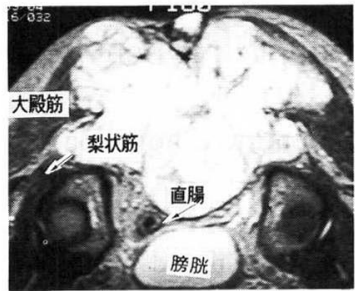

T2 axial
図 4 症例 4.67 歳, 男性

$\mathrm{S} 2 / 3$ 椎間板で腫瘍の浸潤はブロックされてい る. 直腸や膀胱壁への浸潤はみられないが, 大 殿筋や梨状筋へは広範に浸潤していた。

広範に浸潤性の発育していたが，坐骨神経への浸潤は みられなかった。また仙腸関節への浸潤も見られなかっ た（図 4 ).

\section{考察}

MRI が骨軟部腫瘍の拡がりを把握するのに有用で あることは，すでに多くの著者により報告されてい る ${ }^{2)}$ ，そこで本研究では MRI を用いて，仙骨脊索腫 の発育様式が骨, 筋組織, 骨盤内臓器, 春柱管内およ び仙腸関節などの周囲組織の違いによって浸潤の程度 に差があるかどうかを, 自験例 4 例について調査した。 その結果，仙骨脊索腫は浸潤部位によって発育態度に 差がある事がわかった。

すなわち仙・尾骨へは不規則に浸潤していたが，脊 柱管内への浸潤は軽度であった．周囲の筋組織へは大 きくなるに従い仙・尾骨に付着している大殿筋, 梨状 筋，尾骨筋へ結節状の広汎な浸潤が認められた。しか
し骨盤腔内へは圧排性増殖を示すだけで，直腸壁への 浸潤はなかった。また仙腸関節を破壊して腸骨へ浸潤 した例はなかった。

仙骨脊索腫は, 一般的には周囲組織へ圧排性増殖を する悪性度の低い腫瘍とみなされている。この反面, 根治的切除を目指した手術を行なっても局所再発率が 高いことはよく知られた事実である ${ }^{1,3,5,6)}$. この原因 は, 腫瘍の発育様式の把握が不十分なことと神経障害 を惜しむ余り切除縁が甘くなることによると考えられ る. 今回の検討結果は, 仙骨脊索腫の切除の際には, 仙骨内と仙骨に付着している筋内への浸潤増殖性が高 度なことから，これらの部では悪性度の高い腫瘍に準 じた切除縁の設定が必要である事を示唆していた。

ま と め

(1)仙骨脊索腫 4 例の発育様式を MRIにおける病変 の拡がりから検討した。

(2)仙骨および仙骨に付着部をもつ筋組織へは結節性 に強い浸潤増殖を示した。

(3)骨盤腔へは圧迫性増殖を示し直腸との境界は鮮明 であった。脊柱管内の浸潤は軽度で仙腸関節への浸潤 はなかった。

(4)仙骨脊索腫を切除する際には, 以上のことを考慮 した切除縁設定の重要性が示唆された。

文献

1) Kaiser, T.E., Pritchard, D.J. and Unni, K.K.: Clinicopathologic study of sacrococcygeal chordoma. Cancer, $53:$ 2574-2578, 1984.

2) Kevin P.Bethke, James P.Neifeld, Walter Lawrence JR: Diagnosis and management of sacrococcygeal chordoma, J of Surgical Oncology $48: 232-238,1991$.

3) 中条正博ほか: Sacrococcygeal chordoma. 中部整災 誌, $24: 941-947,1981$.

4）日本整形外科学会骨軟部腫瘍委員会編：全国骨腫瘍患 者登録集一覧表，国立癌センター，東京 1988 .

5）大幸俊三，鳥山貞宜：仙尾骨脊索腫の治療と予後。日 整会誌, $63: 240-244,1989$.

6) Smith, J. et al.: Sacrococcygeal chordoma; a clinicopathological study of 60 patients. Skeletal Radiol, $16: 37-44,1987$. 